\title{
Participatory Drama: A Pedagogy for Integrating Language Learning and Moral Development
}

\author{
Joe WINSTON \\ Emeritus Professor of Drama and Theatre Education, Centre for Education \\ Studies, University of Warwick, Coventry, UK \\ j.a.winston@warwick.ac.uk
}

\begin{abstract}
This paper illustrates how integral drama-based pedagogy can be effective in two areas of learning for primary aged children, namely in language development and moral thinking. The activities that demonstrate how the theory can be put into practice are based upon a picture book and show how storytelling and aesthetic playfulness lie at the heart of the process. I argue that the processes used in the pedagogy as much as the content of the lesson itself contribute to children's ethical cultivation, while the story around which the activities are framed draw out from children vocabulary that builds upon and extends what they intrinsically know about how humans ought to treat one another. Each of the activities is thoroughly described so that teachers who are unused to the demands of this pedagogy can see exactly how it can be managed and made to work in the classroom.
\end{abstract}

\section{Keywords}

participatory drama - language learning - moral thinking - applied ethical cultivation - practical application

\section{Introduction}

Participatory drama is a term I use to describe educational practices that have evolved from the traditions of drama and theatre in education. A playful way of teaching that has a growing international research base, it originated in the UK with the pioneering work of Peter Slade (1954), Dorothy Heathcote (Johnson 
and O'Neill, 1984), Gavin Bolton (1979), and with the later work of Jonothan Neelands (1984) and Cecily O'Neill (1995). More recently, practice and research in the field has flourished in English speaking countries such as Australia, New Zealand, Canada and the US but increasingly in South East Asia, noticeably in Taiwan, Hong Kong and more recently in mainland China, where Integral Drama Based Pedagogy (IDBP) can be seen as a new development in the field. ${ }^{1}$ At its base, the practices of participatory drama are founded on the principle that human beings are essentially playful creatures; that the spirit of play is foundational to artistic practices in general and to theatre practice in particular; and that play is an essential pre-requisite to learning and creative thinking. Rather than seeking to expound upon these theoretical propositions, this article sets out to illustrate them through describing how this form of educational drama can work in practice. For this purpose, I present below extracts from a scheme of work aimed at primary aged children between the ages of $8-12$ years, based upon a published picture book called The Boat (Ward and Andrew, 2004).

Although participatory drama can be used across a broad range of curriculum subjects, I will concentrate here on two areas of learning that it is most apt to stimulate and develop in an integrated fashion, namely language learning and moral thinking. Drama arises from language in its fullest, embodied form. It motivates children to talk, question, discuss significant issues, address problems, propose solutions. It also harnesses the emotional and cognitive resources of the body to help them communicate. The body - at best neglected, at worst seen as an unhelpful distraction to the life of the mind in the classroom - becomes central to how children interpret and communicate meanings in drama class. And because of the centrality of stories to the dramatic process, these meanings will often address profound social and moral concerns, as the best stories usually do. ${ }^{2}$

Integrating mind and body the way it does, drama can be seen to constitute a pedagogy in line with the core moral teaching of Wang Yangming. Wang believed that speaking the correct words alone do not constitute knowing and emphasised the centrality of both experience and action to true knowledge. "One must have experienced pain in order to know pain," he wrote; and elsewhere: "Those who know but do not act, simply do not yet know."3 Another

1 See, for example, numerous articles published in the Journal of Drama and Theatre Education in Asia, 2010 to the present day. See also the chapter on IDBP in this volume by Ma and Subbiondo, pp. 499-515.

2 For a full examination of this argument see Winston (2000) which has also been translated into Chinese and published by DKVision in Taiwan.

3 The quotes and other references are taken from pages 6 and 7 of Stanford.edu (2019). 
core aspect of Wang's philosophy was the belief that moral knowledge is innate to all human beings, part of a pattern of mind already fully present in every person. Thus, moral knowing is a process of drawing out (educare in Latin) rather than pressing in. Of course, every teacher will realise that students need structures and rules to guide and shape behaviour; but learning good habits and how to do as one is told cannot be counted as knowledge unless they serve to enlighten students to their shared, common humanity. The rest of this article presents a specific scheme of work, analysed in order to serve both as an example and an explanation of how drama can act as applied ethical cultivation, to bring about moral knowledge through integrating experience, language and action in the classroom.

\section{A Picture Book as Stimulus for Educational Drama: The Boat, by Ian} Andrew and Helen Ward

Through a series of beautiful illustrations and a stark, spare, poetic narrative, The Boat begins with an old man who lives on his own, on a hill, where he looks after a range of animals, all of whom have been abandoned. As well as sheep, cows and horses, he keeps more exotic animal, such as zebras, giraffes and lions. We learn how, on a hill opposite, there is a village but that the old man and the villagers hold each other in mutual suspicion and hostility. He thinks they are greedy and grasping, they think he is strange and ill-tempered. Only a little boy from the village thinks differently. He often watches the old man from a distant vantage point and is impressed by the care and kindness with which he treats the animals. Then one day it begins to rain incessantly until the entire landscape is flooded. Where there had once been land between the hills, there is now a raging flood and the old man's farm is cut off, surrounded by rising floodwater.

From his vantage point on the opposite hill, the boy watches desperately and there seems to be nothing he can do to help the old man and his animals. Then, as if by magic, a boat appears, floating towards him across the raging torrent. Quickly he boards it and rows towards the hill. At first the old man refuses to come, despite the boy's entreaties, but a number of animals are enticed aboard, and the boy rows them back to the village. By now villagers have gathered and are aware of what the boy is doing. They gather to meet him, leading the terrified animals to shelter and building a makeshift raft so that the boy can return across the flood and rescue the rest of the menagerie, the old man's farm being now almost completely under water. This time at the urging of the boy, the old man clambers aboard the boat and, with the rest of the 
animals clinging to the raft, together they row back to the island, where they are greeted warmly by the previously hostile villagers. 'Thank you', are the only words the old man can offer through his tears; and at that moment a rainbow appears in the sky and the rain begins to end.

The story is mythic rather than realistic. There are no names within its narrative, which carries echoes of the tale of Noah's Ark from the Judaeo-Christian tradition. Significantly, it also chimes readily with contemporary issues of climate change. In my own country we have just suffered the wettest winter since records began and, in some regions, there are accounts of whole communities coming together to help those who have been flooded, as happens in The Boat. The concept of community is indeed one that the story can help children consider, framed as it is within a tale in which a child is the one who brings hostile adults together. As in many of the best children's stories, the figure of a child is made to be symbolic of our hope for a better future - as indeed children must be, if the world is to survive and prosper.

Below I will describe some of the key pedagogic strategies used to explore this story, explaining the purpose of each as the article proceeds, focusing on their role within a framework for language learning and moral development as outlined above. This, I believe, is a more apt way to approach the topic than by spending a long time expounding theoretical issues divorced from practical considerations. In my experience, it is far more illuminating and more helpful to teachers and teacher educators to bring theory and practice together.

\section{Opening Activities: The Teacher Takes on a Fictional Role}

The story begins with the sentence 'On a hill among hills lived one old man'. I write this on the board and ask children if this sentence makes them think about the old man in any particular way. Many tell me that they imagine he is alone and wonder if he feels lonely. When questioned, they tell me that this is suggested by the word 'one old man' as opposed to the more usual 'an old man'. It thus draws children's attention to how a careful use of simple words can direct our imaginations; it also creates a pause for them actively to begin to engage with the story by stimulating their curiosity. This is developed by a further activity. I ask them to suggest some questions that they would like to ask the old man if they could meet him. They often suggest, for example, 'Do you live on your own?' 'Are you lonely?' 'Have you always lived on that hill?'

Once I have three questions, I tell the children that I am briefly going to take on the role of the old man. They are to watch me and wait until I speak to them before asking me their questions. Then I put on a woolly hat and mime 
some activities - peering for my animals through the darkness, whistling and smiling as they come to me, looking with a hostile expression at the village in the distance. Of course, the children know nothing about the story yet so this stimulates a further range of questions - 'Is that your pet dog you were calling?' 'What were you looking at when you pulled an angry face?' Often, I ask questions back, in a slightly hostile tone of voice: 'Is it your business whether I like living on my own or not?' which can prompt children to ask me why I am so grumpy. After a very short period of time, I take off the hat, thus signalling that I am no longer in role as the old man and ask the children what they have learned about him through their questioning. Inevitably they now have lots of ideas and are ready to listen to the story with more attention and interest than if I had simply read it to them with no preparation. And, through my taking on a role different from that of the teacher, the children have been able to use a broader range of language than they would have otherwise when talking to me. It is the playful spirit of drama that has managed this.

Teachers unused to drama are inevitably worried about pretending to be someone else in this way. They are not actors, they often say. Besides, children might get too excited and start to speak in inappropriate ways. There are two very important responses to make here. First of all, teachers are actors, social actors, performing their professional role through how they dress, talk and generally comport themselves. As part of this role, they regularly perform a number of attitudes - patiently waiting for quiet, for example, showing that they are slightly cross; showing how pleased they are at a child's work, or how very disappointed they are with a child's behaviour, and so on. Going into role as the old man is an extension of this kind of performance but it allows for a range of non-professional but deeply human attitudes to be performed in the classroom and for children to respond to these.

So, in the case of the old man, he is grumpy and slightly rude in a way that would be unprofessional for a teacher. What children need to know is that the rules of the classroom will be slightly different when the teacher takes on the role of someone different. If these are clarified, they will generally respond accordingly. If they are unused to this kind of work, it might take some time for them to become accustomed to these new rules. In this case the teacher can say. "When I put the hat on, I will pretend to be the old man. Don't speak to him unless he addresses you first. When I take the hat off, I will be talking to you as your teacher." If a child says something inappropriate when you are in role as the old man, you can then readily take off the hat and ask the children to suggest why you have stopped the game. They will know and tell you why. You can then explain that it is important not to be rude to the old man, otherwise he won't talk and they won't be able to find out any more information from him. 
In this way, you are explaining to children the rules of the exchange and why these are important while, at the same time, creating the kind of transitional space that Winnicott (1992) saw as so important in allowing children to bridge fantasy and reality.

\section{Presenting the Story Theatrically}

When teachers read a story to a class, they sometimes simply "put on their storytelling voice" - pleasant enough but without really attending to the tone that the story demands. Such teachers are limiting the performative power of their voices. Once again, it is useful to consider how actors command and hold attention.

With this story I do a number of things to make the whole reading more theatrical or cinematic. I have the book scanned and made into a power-point presentation, so that the words and pictures are large, almost like a film. I darken the room and use suitable background music as a kind of soundtrack - music that is ominous and atmospheric, to match the danger brought by the flood. ${ }^{4}$ Finally, I use my voice carefully, reading the story in a way that emphasises its serious, epic qualities and the rhythmic, alliterative qualities of the prose. This serves to lure children into the story world, to create a solemn though exciting atmosphere, different from one they would normally anticipate in a classroom and to draw attention to the story's language in an enjoyable way. The reading only takes seven or eight minutes - a short enough time for children's attention to be held. Once it is finished, I ask them to talk with the person next to them in order to find five adjectives they would use to describe this story, noting and displaying their suggestions.

\section{$5 \quad$ Enacting the Story Spontaneously}

The next activity is perhaps the most openly playful of all. It is very active and invariably gives rise to a lot of laughter. It nonetheless develops a range of important skills and attitudes that have social and moral implications for how children are to work together. The activity has become extremely popular in the UK since the Royal Shakespeare Company began to make use of it as a means to introduce schoolchildren to Shakespeare's plays. ${ }^{5}$

4 I use the track 'Dolphin' from the album Bones by Gabrielle Roth and the Mirrors.

5 The Royal Shakespeare Company, based in Stratford-upon-Avon, UK, call this activity the 'Whoosh' and acknowledge my own invention of it (2010). 
Children are asked to sit in a circle. Holding a 'story wand' - a small stick of some kind - in my hand, I inform children that we will now hear the story again only this time we will also see it spontaneously come to life in front of our eyes, as they will act it out inside the circle. Children are to volunteer to play all characters (including the animals) and to create the set and the props (the boat and the raft, for example; also the wind, rain and the flood itself). They are to raise their hand if they are willing to join in when the teacher as storyteller invites them to do so. Those children who are less willing to enter the circle can be given vocal roles - the sound of the wind and rain, for example, or of the terrified animals as the flood waters rise. The teacher controls the activity through her story wand; at any moment she can wave it through the air, saying 'Whooooosh!!' as she does so, the signal for all to sit down and for new volunteers to play the various characters and properties once the story continues.

This highly enjoyable, physical and noisy activity performs a number of significant functions in addition to serving as a way to revisit the plot of the story and hence help children remember it. It draws on the human proclivity for play and brings energy and joy into the classroom; it encourages children to co-operate with one another spontaneously, as they link arms unthinkingly to form the raft or boat, for example, or get close to one another as they huddle together as frightened animals. Such spontaneous, communal playfulness helps establish what performing artists call the spirit of the 'ensemble' - an ethos of trust and togetherness that encourages children to take risks and be creative, as well as establishing the need for them to listen carefully and work socially, as a group. Here the moral potential of drama work can be located in the process of its participatory practices as well as in the content and structure of the story that we are about to explore. In Aristotelian terms, it is a process of ethical education by encouraging good habits (1955); but its integration of knowing through action is also very much in the tradition of applied ethical cultivation propagated by Wang Yangming.

Of course, many qualities disappear when we perform the story in this way. The beautiful language, the serious themes are replaced by spontaneous storytelling and energetic laughter. But, as with theatre itself, the narrative of a lesson needs rhythmic variety if it is to hold concentration and bring different aspects of our humanity into play. Without such aesthetic considerations, as the American philosopher John Dewey (2005) emphasised, the result is that a lesson can all too easily become anaesthetic - dulling our senses rather than stimulating our interest. In this direction boredom lies! 
Children are now required to work in groups of five. Teachers can organise this in different ways but there are various games one can play that encourage children to form groups quickly and spontaneously, thus encouraging them to work with a range of classmates who are not necessarily their chosen friends. Once in their groups, I ask each group to reflect upon the story in order to find different, specific moments from it - moments of co-operation; loneliness; fear; hope; kindness; courage or reconciliation. Each group is given a different moment to locate. So, the co-operation group might choose the moment when the boy and the man are rowing together, or when the villagers are working together to create the raft; the hope group might choose the moment when the boat first appears.

Whichever they choose, the groups are asked to create a still image or tableau of this moment, so that all of the other groups can see clearly what they have selected. They are also asked to emphasise those qualities within their image that mark it as a moment of co-operation, or hope, or whatever focus they have been given. When these images are performed, the rest of the class is asked to identify which moment of the story is being depicted; how the group has emphasised the particular focus they were given; and also to state two things they liked about the image, explaining why. This framing of the questions is important as it helps develop a moral vocabulary within the class. By considering how we recognize and where we find virtues such as courage, hope, kindness and so on, children will gain greater conceptual understanding of them. In this sense, we can consider the virtues as 'thick concepts', as the philosopher Bernard Williams has called them (1985); concepts that are innate to us as human beings, that children can readily recognize and discuss if we give them the space to do so. By asking the class to think about two things they like about each image, we are also helping children to develop a critical vocabulary whilst ensuring that sensitive or isolated children are not damaged by hurtful remarks. Children need to feel secure when they show their work; such simple procedures help develop trust and confidence, personal attributes valuable to sustaining a healthy ethos in any classroom.

The teacher can now put on a questioning face and say 'I wonder why the old man chose to live all those years on his own? Let's suppose that he never used to live on that hill but that something happened in his past, when he was much 
younger, that made him want to isolate himself from every other human being. I wonder what might have caused this?' Once again the teacher is acting differently here, as one who cannot possibly know all the answers, who can only imagine, like the children, who are now asked to talk with those near them to think of different possibilities, which can then be shared with the whole class and noted on a flipchart or white board. Another game can then be played so that children form new groups of four or five. Each group is now to invent its own story to explain the mystery of the old man's past and they are to do this through a process known as "acting out."

"Acting out" is not the same as performing for an audience. It involves children in the kind of fluid, representational, make believe play that they will often embark upon quite naturally at this age, in which they take on roles to improvise a story, changing them for new roles whenever necessary, commenting freely on the action and suggesting new ideas as they do so. Once they have acted out their ideas in this way, children will have a clear idea of the story they have to tell but it will not yet be ready to share with an audience. The teacher now has a range of options open to her. If she wants the children to shape their ideas into a brief performance - and children often want to do this - she needs to offer them a simple structure. The easiest way is for them to be given the task of making a very short play - fifteen seconds long, no more - which is to portray the most important part of their story and in which everyone in the group must have two or three lines of dialogue each. These simple rules will help children decide upon their key ideas and will ensure that those who are quiet and shy are not left out of the process and that more dominant children cannot do all of the talking.

There are other possibilities open to the teacher, however. She can, for example, ask the groups to script this performance with stage directions, rather than show it to the rest of the class. This script can then be passed on to another group to interpret and perform, so that children thus experience what it is like to be both actors and playwrights. Performance of the story is not entirely necessary as it can be communicated in other ways. For example, the teacher might ask children to find a partner from a different group. They are then each given two minutes to tell their respective stories to one another as a story, beginning 'Once there was a young man ...' When not telling their own story, they are listening to that of their partner and teachers can playfully demand that they do this as 'the best listeners in the world' - looking at their partner while they speak, asking helpful and interested questions on occasion and telling their partner what they really liked about their story once it is finished. Playful, perhaps, but such rules do help develop security, trust and the spirit of togetherness which group activities such as drama need if they are 
to thrive. And the result is that most children will now be very happy to write down their stories and present these written, illustrated versions for others to read.

The sharing of the stories is important. In developing them, children have been empathising with someone different in age, situation and experience from themselves, achieving this through their feelings of common humanity. Children will often, for example, imagine a story in which the old man, when younger, lost those close to him through some form of betrayal or tragedy - in a war, or in an accident of some kind. In such cases, it is grief that has driven him to live on his own and it is to animals that he has turned in his need for companionship and love. Of course, they may not express this understanding so eloquently but it can be drawn out from them through discussing what they have imagined and witnessed together in creating and sharing these stories - another example of the moral energy that drama can bring to the classroom, an energy very different from that of being preached at or instructed on how to behave. Once again, we have an example of how drama can cultivate children communally to apply their innate, ethical knowledge to action, albeit within the imagined framework of a story.

Rather than thinking of moral behaviour in terms of rules and the simple binaries of right and wrong, philosophers such as Alasdair MacIntyre (1981) and Bernard Williams (1985) have proposed that we should consider moral activity in terms of human virtues that we appreciate on an affective level and come to understand through their practice in different contexts and situations. 'Courage', for example, is a virtue admired in all cultures but understood through its expression in actions determined by specific circumstances: the courage of a soldier, the courage of an intellectual, the courage of a mother, the courage of a young boy will manifest themselves differently but nonetheless be readily recognizable as courage. Similarly, feminist ethical philosophers such as Carol Gilligan (1982) and Nell Noddings (2003) have identified the virtues we associate with care and with caring as a specific ethical arena to complement the more 'masculine' concern with issues of justice and fairness. ${ }^{6}$ In order to develop children's moral understandings, then, we need to develop their conceptual understanding of the virtues and here language - and language play

6 In this they were taking issue with the rationalist theory of moral education proposed by Kohlberg (1971). See Winston (1998) Chapter 1 for a full discussion of this debate. 
- can be central, as illustrated in the simple game below and the writing activities it stimulates.

The teacher can remind the children of how the boy watches the man and is impressed by the kindness and care he shows to the animals. 'What sort of things must we do when caring for animals?' she can ask. Many children will know this from first-hand experience - cleaning out the cage of a pet rabbit, for example, feeding it the right food and taking care of it in various ways when it is ill. The three categories of feeding, cleaning and curing will thus quickly emerge as areas within which we demonstrate care for animals. Looking again at the pictures in the book, the children can be asked to list some of the animals that the old man keeps. Then the teacher can tell them that she will demonstrate how he cares for one of them, whereupon she will, once again, become an actor in a very straightforward manner by miming a simple activity such as grooming a horse - smiling, patting its nose, picking up an imaginary brush and running it along its body from mane to tail.

When children are asked to identify this activity, they will likely say 'brushing' rather than 'grooming', which presents the opportunity for developing new vocabulary. Now that they understand the game, children can work in pairs as $\mathrm{A}$ and $\mathrm{B}$, with $\mathrm{A}$ in role as the old man miming an act of care or kindness to a specific animal, taken from the list of those the old man keeps that have been written on the board. Perhaps he is removing a painful tooth from the lion, or rescuing a lamb from brambles, or feeding the chickens, or cuddling a baby duckling. B has to watch and work out exactly what this act of care consists of, calling out her ideas as she has them. A is not allowed to speak but can respond through gesture or by changing what she is doing to make her meaning clearer, as in the popular party game Charades. When B finally has guessed correctly, the two partners swap roles. The teacher can keep the game going for at least three minutes as this will force the children to think very hard as they exhaust the most obvious ideas.

The teacher can now ask each pair to write down the various jobs they mimed: for example, the old man took out a painful tooth from the lion's mouth; he rescued a lamb from some brambles, asking them to be as precise with their vocabulary as possible. Some of these can be shared on the board and children can now be asked to consider the qualities the old man had to demonstrate in each case and add this to the writing. "The old man was very patient when he took out the painful tooth from the lion's mouth; he was very careful not to hurt the lamb when he rescued it from the brambles; he was very thorough when he groomed the horse," and so on. Once these have been written, the teacher can gather a number together and read them out loud, asking the children if they think the villagers might change their ideas about the old man if they could 
only see him in this way. They are thus being helped to identify certain qualities as virtues - patience, care, thoroughness and so on - as well as to develop their vocabulary. In this case, children are focusing on the caring virtues that they instinctively know and value, using drama to explore, discuss and make them recognizable through action.

\section{$9 \quad$ The Boy Crosses the Flood Waters}

In what is perhaps the most dramatic moment of the story, the boy demonstrates great courage as he rows the boat across the flood in his attempt to rescue the old man and his animals. In order to capture the dramatic tension of this journey, the teacher can suggest to the children that, as he rowed, the boy imagined he could hear voices through the wind and the storm. Sometimes it sounded as though these voices were urging him onward, sometimes it seemed they were urging him to turn back. She can then create two columns on a flipchart or on the board and ask children what they imagine these voices might have been saying, writing their suggestions in the appropriate column - Carry on, they need your help and Don't turn back! the animals are in danger in one column, for example, with phrases such as Turn back now or you will drown and There is no room in your boat to rescue them all in the other. There should be at least five suggestions in each column. Once this is done, the class can be divided into two groups - the positive 'carry on' group and the negative 'turn back' group - and they can be asked to choose silently at least one of the phrases from their list to learn by heart.

The two groups can now be organised into two lines facing one another, about two or three meters apart. First, they are to practise vocally making the sounds of the storm together - the whistle of the wind, the crash of the waves - which the teacher can conduct so that it increases and decreases in volume. Then they can be asked to repeat this but to intersperse the sounds of the storm with a loud whispering of their chosen phrase at certain moments of their choosing. As they do this, the teacher can organise two or three children to carry a rough model of the boat between them, over a small, billowing cloth of blue silk. Taken all together, this can create a surprisingly effective, symbolic version of the journey, which can be repeated two or three times more, this time with the teacher leading different children one at a time, blindfolded, slowly between the two lines, asking each child to make sure that their phrases are clearly heard as the blindfolded child passes them. Once the blindfold is removed, these children can be asked to share what the experience felt like - terrifying, perhaps, or confusing, or bewildering - and to recall which of the phrases they remember hearing as they passed between the lines. The class 
can now be asked to write, in the voice of the boy, a paragraph evoking his journey across the floodwaters, using the words and the emotional memory of this exercise as the raw materials for doing so.

\section{Building the Raft of Community}

A final exercise can help the children reflect upon how the disaster of the flood has brought the two hostile camps together - the old man and the villagers. In the story the villagers build a raft from everything they have available to them, such as old tin baths and barrels. Children can be reminded of this and asked to imagine that each piece of the raft was a way of saying something to the old man, words intended to repair the animosity between them. Each child is provided with a piece of $\mathrm{A}_{4}$ paper and asked to write on it what they think this might have been. Then, as a form of ritual, they can sit in a circle and enter the space inside it one at a time, as villagers, symbolically building the raft together from the individual pieces of paper, saying their sentences out loud as they place it on the floor. Phrases such as: 'We want to help you and your animals' or 'We don't want you to drown - come and join us!' will be common. A neater, coloured, illustrated version of each of these sentences can later be made for display purposes under the heading The Raft of Community. A raft, of course, needs to be tied together. With this raft, of words and of feelings, the teacher can suggest that it will not be rope that keeps it together but human qualities and desires, asking the children what they think these might be. The letters for each of the words they suggest can then be cut out and organised in the shape of the ropes that bind the words of the villagers together, thus creating through art an image that Aurobindo would surely have recognized as symbolic of our search for unity in diversity (Ma and Subbiondo, 2021 see pages 503-504).

And of course there is the boat itself that pulls this raft. In the book, it has no name. Can the children suggest a name apt enough for a boat capable of steering the raft of community? Many words spring immediately to my own mind - hope, compassion, empathy, kindness, justice, mutuality and so on. But, after this extensive transdisciplinary drama work, children will certainly have their own ideas.

In this article I have outlined a range of activities from one scheme of work intended to demonstrate some of the key educational principles of participatory drama and a few of the strategies that can be deployed to realise the 
aims of Integral Drama Based Pedagogy. The power of this form of pedagogy, I have emphasised, lies in its two fundamental characteristics: its playfulness and its use of story. Good stories provide the content and dynamism to harness and maintain children's interest, whilst playfulness can bring enjoyment and energy to the process of learning, even when the issues being explored are morally profound, as in the story of The Boat. In order to incorporate participatory drama successfully into their practice, teachers do need to be prepared to develop and take risks with their pedagogy. They must embrace pretence and artfulness; they must be prepared to use classroom space so that the body can be used actively and communicatively; they must develop practices that encourage trust, risk taking and togetherness; and they must refrain from seeing work and play as totally distinctive categories. In this sense, they are drawing knowledge from a range of disciplines including sociology, psychology, anthropology and moral philosophy as well as from arts and drama practices. If the scheme presented in this chapter is one of integrated learning, then the teaching, too, is evidently a form of transdisciplinary, integrated pedagogy. The challenges it presents to teachers might initially seem great, but these are surely outweighed by the benefits it can bring to their students.

\section{References}

Aristotle. 1955. Ethics. Translated into English by J.A.K. Thomson. Harmondsworth UK: Penguin.

Bolton, Gavin. 1979. Towards a Theory of Drama Education. London: Longman.

Dewey, John. 2005 [1934]. Art as Experience. New York: Perigree Books.

Gilligan, Carol. 1982. In a Different Voice: psychological theory and women's development. Cambridge, MA: Harvard University Press.

Johnson, Liz and O'Neill, Cecily. 1984. Dorothy Heathcote: Collected Writings. London: Hutchinson Press.

Kohlberg, Lawrence. 1971. "Stages of Moral Development as a Basis for Moral Education." Beck et al (ed.) Moral Education: Interdisciplinary Approaches. Toronto: University of Toronto Press.

Neelands, Jonothan. 1984. Making Sense of Drama. London: Heinemann.

Noddings, Nell. 2003. Caring: a feminine approach to ethics and moral education. Berkeley: University of California Press.

Ma, Liwen and Subbiondo, Joseph L. 2021. "Integral Drama Based Pedagogy as a Practice of Integral Education: Facilitating the Journey of Personal Transformation." Beijing International Review of Education, 499-515.

MacIntyre, Alasdair. 1981. After Virtue: a study in moral theory. London: Duckworth. 
O'Neill, Cecily. 1995. Drama Worlds: a Framework for Process Drama. London: Heinemann.

Royal Shakespeare Company. 2010. The RSC Shakespeare Toolkit for Teachers. London: Methuen Drama.

Slade, Peter. 1954. Child Drama. London: London University Press.

Stanford Encyclopedia of Philosophy. 2019. Wang Yangming. https://plato.stanford. edu/entries/wang-yangming.

Ward, Helen and Andrew, Ian. 2004. The Boat. Dorking, UK: Templar.

Williams, Bernard. 1985. Ethics and the Limits of Philosophy. London: Fontana Press.

Winnicott, Donald W. 1991 [1971]. Playing and Reality. London: Routledge.

Winston, Joe. 1998. Drama, Narrative and Moral Education. London: Falmer.

Winston, Joe. 2000. Drama, Literacy and Moral Education 5-11. London: David Fulton. 